\title{
Supplementation of Nellore young bulls on Marandu grass pastures in the dry period of the year ${ }^{1}$
}

\author{
Marcella de Toledo Piza Roth², Flávio Dutra de Resende ${ }^{2,3}$, Gustavo Rezende Siqueira ${ }^{2,3}$, \\ Rodolfo Maciel Fernandes ${ }^{4}$, Letícia Custódio ${ }^{4}$, Anna Paula de Toledo Piza Roth ${ }^{2}$, Matheus \\ Henrique Moretti ${ }^{2}$, Wellington da Costa de Campos ${ }^{4}$
}

\author{
${ }^{1}$ Research project conducted with the aid of Fapesp (Process no. 2008/55837-4). \\ ${ }^{2}$ Departamento de Zootecnia da FCAV/Unesp, Campos de Jaboticabal/SP, Brazil. \\ ${ }^{3}$ APTA, Regional da Alta Mogiana, Colina/SP, Brazil. \\ ${ }^{4}$ Departamento de Zootecnia do Centro Universitário da Fundação Educacional de Barretos/SP, Brazil (UNIFEB).
}

\begin{abstract}
The objective of this study was to evaluate performance and daytime ingestive behavior of 84 Nellore young bulls in the post-weaning phase kept on Brachiaria brizantha cv. Marandu pastures during the dry season. Treatments were protein mineral supplementation ( $1 \mathrm{~g} / \mathrm{kg}$ body weight) and protein+energy mineral supplementation ( $3 \mathrm{~g} / \mathrm{kg}$ body weight). The experimental area comprised 12 paddocks in a total area of 27.36 ha, divided in two blocks of six paddocks each, having three replications per treatment in each block, with 42 animals/treatment. The data were subjected to variance analysis with repeated measures over time via procedure PROCMIXED of SAS (Statistical Analysis System, version 9.0) and means were compared by the Tukey test at 5\% probability. The initial average weight of animals was $204.8 \mathrm{~kg}$; final weights were 260.9 and $276.9 \mathrm{~kg}$ for animals that received protein and protein+energy supplement, respectively. The forage availability, sward height and stocking rate values did not differ with supplementation, but they showed difference between the experimental periods. The average time spent grazing during daylight of animals fed protein+energy supplement was shorter as compared with those which consumed protein supplement. Animals kept under the same pasture conditions during the dry season show better performance when they receive protein+energy supplement than protein supplement.
\end{abstract}

Key Words: animal performance, Brachiaria brizantha, post-weaning phase

\section{Introduction}

Weaning is the moment of permanent separation between mother and offspring, causing a period of stress for both, from the productive viewpoint. In this moment, all attention should be drawn to the newly-weaned animal, which usually presents weight loss and greater susceptibility to the occurrence of diseases due mainly to two factors: nutritional deficiency and stress caused by the separation from the mother; the latter can be minimized when weaned animals are kept in the company of others from the same lot (Haddad \& Mendes, 2010).

In this scenario, the nutritional factor must be carefully regarded, especially considering that weaning is usually performed in the dry period of the year, when forages present reduced nutritional value and result in unsatisfactory animal performance. Thus, according to Baião et al. (2005), it is necessary to supply concentrate supplements to correct the nutritional deficiencies of the pasture, allowing for better performance and reduction of the production cycle and the slaughter age of animals.
According to Paulino et al. (2002), supplementation is an alternative to keep the adequate level of intake of nutrients necessary to meet the requirements of grazing animals, provided the forage mass is not limiting. According to Reis et al. (2004), supplementation strategies during the dry period of the year can vary a lot. Considering weaning young bulls, the gains can be from low to moderate (up to $300 \mathrm{~g} /$ animal.day), allowing for the maintenance of weight or even gains, which can reflect in reduction in the postweaning time, ensuring anticipated leave from areas in the properties and slaughter of younger animals with carcasses of better quality.

Supplementation with nitrogenous compounds at amounts that allow for elevating the crude protein content of the diet to levels close to $8 \%$ provides optimization in the use of low-quality forage by grazing cattle (Lazzarini et al., 2009). However, according to Ladeira et al. (2007) multiple supplements, containing protein and energy, should be utilized when one aims at optimizing animal performance.

Therefore, the objective of this study is to evaluate the effect of supplementation on performance and daytime 
ingestive behavior of Nellore weaned young bulls kept on a Brachiaria brizantha cv. Marandu pasture during the dry period of the year.

\section{Material and Methods}

The experiment was conducted at the Research Unit of Pólo Regional de Desenvolvimento Tecnológico dos Agronegócios da Alta Mogiana (PRDTA - Alta Mogiana), in Colina - SP, Brazil, which is a part of the Agency of Agribusiness Technology of São Paulo State (Agência Paulista de Tecnologia dos Agronegócios - APTA). PRDTA - Alta Mogiana is located in the municipality of Colina, São Paulo State, Brazil. The climate of the region is classified as AW (according to the Köppen classification), where the average temperature of the hottest month is superior to $22{ }^{\circ} \mathrm{C}$ and higher than $18{ }^{\circ} \mathrm{C}$ in the coldest month.

The experimental area was cultivated in 2003 with Brachiaria brizantha cv Marandu and is now divided in 12 paddocks that vary from 2.16 to 2.40 ha each, with drinkers and troughs for supplement, allowing for continuous grazing. The soil was fertilized with ammonium nitrate (40 kg N/ha) in the first fortnight of April 2008, at the end of the rainy period and subsequently paddocks were closed until the beginning of the experiment, in July, so as to guarantee an adequate forage mass to the animals during the dry season (July to December).

The precipitation levels were typical for the region, with mean maximum temperature of $30.5^{\circ} \mathrm{C}$ and minimum of

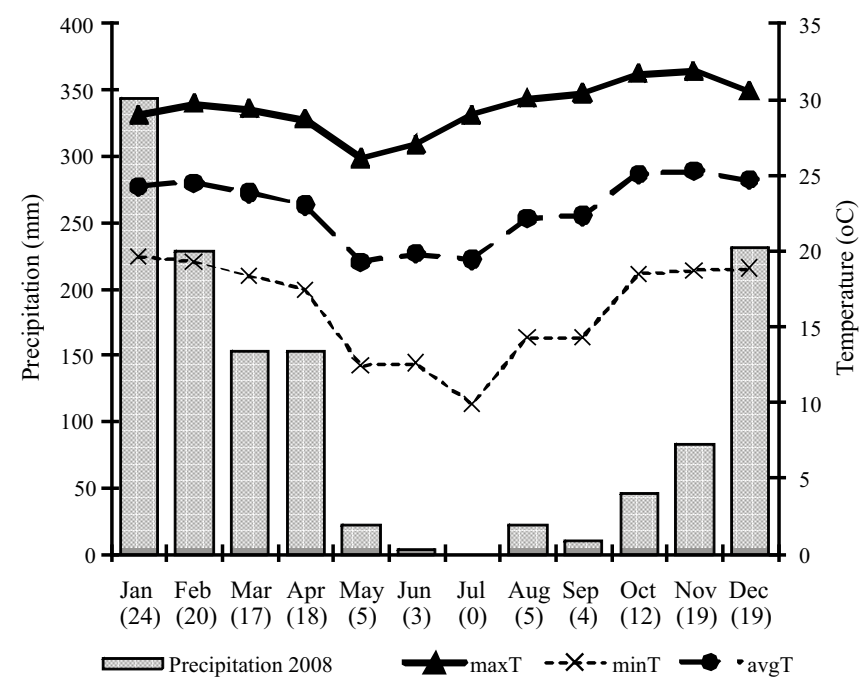

Numbers in parentheses represent the number of days with rain. Source: meteorological station of Apta - Colina, SP, Brazil.

Figure 1 - Precipitation and maximum $(\operatorname{maxT})$, average $(\operatorname{avgT})$ and minimum $(\operatorname{minT})$ temperatures in the months of 2008 . $15.7^{\circ} \mathrm{C}$ (Figure 1). In the fall of 2008 (March to May) there was a good incidence of rainfall $(320 \mathrm{~mm})$, which favored pasture growth before the beginning of the experiment.

Test animals totaled 84 non-castrated post-weaning Nellore cattle, at 8 months of age. At the beginning of the experiment, young bulls were weighed after previous solid and liquid-deprivation for 16 hours, wormed and identified with an earring. In addition to them, 18 animals were utilized for adjusting the paddock loads (reserve animals). Test animals were distributed in the 12 experimental units at a rate of 42 test animals/treatment, divided in 6 paddocks (replications per treatment).

The technique adopted for maintenance of homogeneity in forage availability at the paddocks during the whole experimental period was the put-and-take method, described by Euclides \& Euclides Filho (1997), wherein test animals are kept on the area during the whole experiment and reserve animals are put on and removed from paddocks whenever necessary to adjust forage availability.

The number of animals per paddock was determined according to the forage mass available in every paddock at the beginning of the experiment and at every evaluation period, which along with the average initial weight of animals allowed for establishing the initial stocking rate for the paddocks. The method adopted was continuous grazing with variable stocking rate according to treatments.

The pasture was evaluated and the weight of tester animals and average weights of the lot (sum of weight of tester and reserve animals) were measured at every 42 days for adjustment of the animal load.

Two treatments were evaluated: one with a low-intake protein mineral supplement (1 g/kg body weight - BW) and another with an average-intake protein+energy mineral supplement ( $3 \mathrm{~g} / \mathrm{kg} \mathrm{BW}$; Table 1). Each treatment was composed of six lots of seven animals, in each paddock. Animals were evaluated during four grazing cycles, which lasted 148 days, finishing in December 2008.

Table 1 - Nutritional levels of the supplements utilized

\begin{tabular}{lcc}
\hline \multirow{2}{*}{ Nutrients } & \multicolumn{2}{c}{ Supplement } \\
\cline { 2 - 3 } & PS & PES \\
\hline Crude protein (g/kg DM) & 525.5 & 291.5 \\
Non-protein nitrogen (g/kg CP) & 620.0 & 310.0 \\
Total digestible nutrients estimated (g/kg DM) & 440.0 & 600.0 \\
\hline
\end{tabular}

DM - dry matter; CP - crude protein.

PS - protein mineral supplement (mineral premix composed of $66.0 \mathrm{~g}$ calcium $/ \mathrm{kg}$; $15.0 \mathrm{~g}$ phosphorus $/ \mathrm{kg} ; 2.0 \mathrm{~g}$ magnesium $/ \mathrm{kg} ; 15.0 \mathrm{~g}$ sulfur $/ \mathrm{kg} ; 40.0 \mathrm{~g}$ sodium $/ \mathrm{kg}$ $260.0 \mathrm{mg}$ copper $/ \mathrm{kg} ; 200.0 \mathrm{mg}$ manganese $/ \mathrm{kg} ; 960.0 \mathrm{mg}$ zinc $/ \mathrm{kg} ; 19 \mathrm{mg}$ iodine $/ \mathrm{kg}$; $15 \mathrm{mg}$ cobalt $/ \mathrm{kg} ; 5.0 \mathrm{mg}$ selenium $/ \mathrm{kg} ; 150.0 \mathrm{mg}$ fluorine $/ \mathrm{kg} ; 200.0 \mathrm{mg}$ monensin $/ \mathrm{kg}$ ). PES - protein+energy mineral supplement (mineral premix composed of $23.0 \mathrm{~g}$ calcium $/ \mathrm{kg}$; $6.0 \mathrm{~g}$ phosphorus $/ \mathrm{kg} ; 1.0 \mathrm{~g}$ magnesium $/ \mathrm{kg} ; 3.0 \mathrm{~g}$ sulfur $/ \mathrm{kg} ; 13.0 \mathrm{~g}$ sodium $/ \mathrm{kg} ; 40.0 \mathrm{mg}$ copper $/ \mathrm{kg} ; 30.0 \mathrm{mg}$ manganese $/ \mathrm{kg} ; 148.0 \mathrm{mg}$ zinc $/ \mathrm{kg} ; 3 \mathrm{mg}$ iodine $/ \mathrm{kg} ; 2.4 \mathrm{mg}$ cobalt $/ \mathrm{kg}$; $0.8 \mathrm{mg}$ selenium $/ \mathrm{kg} ; 60.0 \mathrm{mg}$ fluorine $/ \mathrm{kg} ; 80.0 \mathrm{mg}$ monensin $/ \mathrm{kg}$ ). 
Protein supplement was formulated (\% DM) with cottonseed meal (41.9\%), pelletized citrus pulp (8.0\%), urea (12.4\%), sodium chloride (11.5\%) and mineral premix (26.2\%). The protein+energy supplement was formulated (\% DM) with cottonseed meal (31.6\%), pelletized citrus pulp $(56.2 \%)$, urea $(3.4 \%)$, sodium chloride $(3.7 \%)$ and mineral premix $(5.1 \%)$. Supplements were provided to animals every day in uncovered troughs, distributed across the paddocks, in the morning.

Forage mass was determined via adapted doublesampling method of Sollenberger \& Cherney (1995), where in destructive estimates were associated with evaluations of the sward height using the rising plate.

Sward height was measured at every 42 days with a rising plate meter at 50 points per paddock and the average compressed height was calculated. All the forage within the perimeter of the rising plate $\left(0.25 \mathrm{~m}^{2}\right)$ was collected at nine points per paddock, of which three were at the average height, three at points of higher heights and three at points of lower heights, defined by standard deviations above and below the average height, respectively. This forage was placed in indentified plastic bags and taken to a laboratory, where they were weighed, dried in an air-circulation oven at $55{ }^{\circ} \mathrm{C}$ for 72 hours and then weighed again. After obtaining the pairs of data on forage height and mass, linear regression was determined. From the equations, the height values were transformed into forage mass per hectare.

The non-compressed sward height was also measured at every 42 days with a stick graduated in centimeters. Fifty readings were obtained at random per paddock. The measurement of quantitative and structural components of the forage sward was performed through the samples harvested at the average height points and separated in four fractions; fraction one was composed of a green leaf blade (green leaf), fraction two was composed of green stem and leaf sheath (green stem), fraction three was composed of senescing leaf blade (senescing leaf) and fraction four was composed of senescing stem and sheath (senescing stem). After separation, the different fractions were weighed and dried in a forced-circulation oven at $55^{\circ} \mathrm{C}$ for 72 hours and weighed again.

Simulated grazing was evaluated four times, one at every grazing cycle (every 42 days). Forage samples were collected to estimate which portion of the grasses was being consumed by experimental animals. Firstly all grazing animals of the paddocks were observed, so the observers got close to animals randomly to perform the collection according to what was consumed. The samples obtained by the two observers, in each paddock, were taken to the laboratory and homogenized, generating a composite sample, which was then taken to a forced-ventilation oven at $55^{\circ} \mathrm{C}$ for 72 hours.

Chemical analyses of forage and supplements were conducted after grinding them in a Wiley knife mill with $1.0 \mathrm{~mm}$ screen sieve. The dry matter (DM) and crude protein (CP) contents were determined according to the AOAC (1990); fraction A of the protein (non-protein nitrogen NPN) was determined according to Sniffen et al. (1992); neutral detergent fiber (NDF) and acid detergent fiber (ADF) were determined according to Robertson \& Van Soest (1981); and lignin was determined in 72\% sulfuric acidinsoluble residue (Van Soest, 1994) minus contamination by ash. The in vitro true dry matter digestibility (IVDMD) was determined according to the method of Van Soest \& Robertson (1985).

In the determination of duration of daytime grazing, the animals of each paddock were identified by numbers from one to seven in the region of rump and shoulder. The grazing behavior of the seven animals of each experimental paddock was observed individually for two consecutive days during daytime (12 hours); observations were recorded at every ten minutes with the aid of binoculars. At the end, measures inherent to the grazing activities of each animal were summed to identify the time spent in each activity. The daytime period was divided in four moments: early (6h00 to $8 \mathrm{~h} 50)$ and late ( $09 \mathrm{~h} 00$ to $11 \mathrm{~h} 50)$ morning and early (12h00 to $14 \mathrm{~h} 50)$ and late (15h00 to 17h50) afternoon. The percentage of grazing animals was divided in the same manner, so as to determine the grazing peaks.

At the determination of weight gain, animals were weighed at time zero (beginning of the experiment - July 2008) and subsequently at every 42-day period, always after a previous solid and liquid-depravation period of 16 hours. Stocking rate was calculated based on the average individual weight and the number of animals in each paddock during the period evaluated (AU/ha), considering the weight of test and reserve animals as one animal unit (AU), defined as $450 \mathrm{~kg}$.

The data were analyzed in a completely randomized block design with repeated measures over time, in which the block factor was the location of paddocks. The model adopted was mixed, as described below. The paddock set with seven young bulls was used as experimental unit. Data were analyzed through procedure PROC MIXED of SAS (Statistical Analysis System, version 9.0), utilizing the option repeated; means were compared by the Tukey test at $5 \%$ probability.

The model utilized was: $\mathrm{Y}_{\mathrm{ijk}}=\mu+\mathrm{b}_{\mathrm{i}}+\mathrm{S}_{\mathrm{j}}+\mathrm{p}_{\mathrm{k}\left(\mathrm{i}^{*} \mathrm{j}\right)}+\mathrm{T}_{1}+$ $\mathrm{ST}_{\mathrm{j} 1}+\mathrm{e}_{\mathrm{ij \textrm {k }}}$. 
Where: $\mu=$ overall mean; $b_{i}=$ random effect of block $(\mathrm{i}=1$ to 2$) ; \mathrm{S}_{\mathrm{j}}=$ fixed effect of dry-season treatment $(\mathrm{j}=$ PS, PES); $\mathrm{p}_{\mathrm{k}\left(\mathrm{i}_{\mathrm{*}} \mathrm{j}\right)}=$ random error A, paddock within block $\times$ treatment interaction $(\mathrm{k}=1$ to 6$) ; \mathrm{T}_{1}=$ effect of time (period) $(1=1$ to 4$) ; \mathrm{ST}_{\mathrm{jl}}=$ interaction between dry-season treatment and time; $e_{i j k l}=$ overall error; where $p_{k\left(i^{*}{ }_{j}\right)}$ and $e_{i j k l}$ are independent of each other.

In the data on animal performance and forage characteristics, the times of evaluation were considered period (time); and in the data of ingestive behavior, the times of the day were considered period, totaling four periods in the two models. The structures of variance and covariance matrices for the residue (VC, CS, UN, UN(1), AR(1), TOEP, TOEP(2), ARH(1), ARMA(1,1), CSH, HF, $\operatorname{ANTE}(1), T O E P H)$ were tested so as to determine the structure that would best fit each characteristic. The matrices for each variable were chosen according to the BIC (Bayesian Information Criterion). When significant, interactions were deployed through procedure SLICE.

\section{Results and Discussion}

The height of the forage sward (Figure 2) varied over the experimental periods, showing highest value $(\mathrm{P}<0.05)$ in the first period $(47.4 \mathrm{~cm})$, intermediary values in the second $(41.5 \mathrm{~cm})$ and third period $(41.8 \mathrm{~cm})$ and lowest value in the fourth period $(7.5 \mathrm{~kg}$ dry matter $/ \mathrm{kg}$ body weight $-\mathrm{kg} \mathrm{DM} / \mathrm{kg} \mathrm{BW}$ ), remaining superior during the first three periods $(13.5,13.1$ and $12.4 \mathrm{~kg} \mathrm{DM} / \mathrm{kg} \mathrm{BW}$ in periods 1,2 and 3 , respectively).

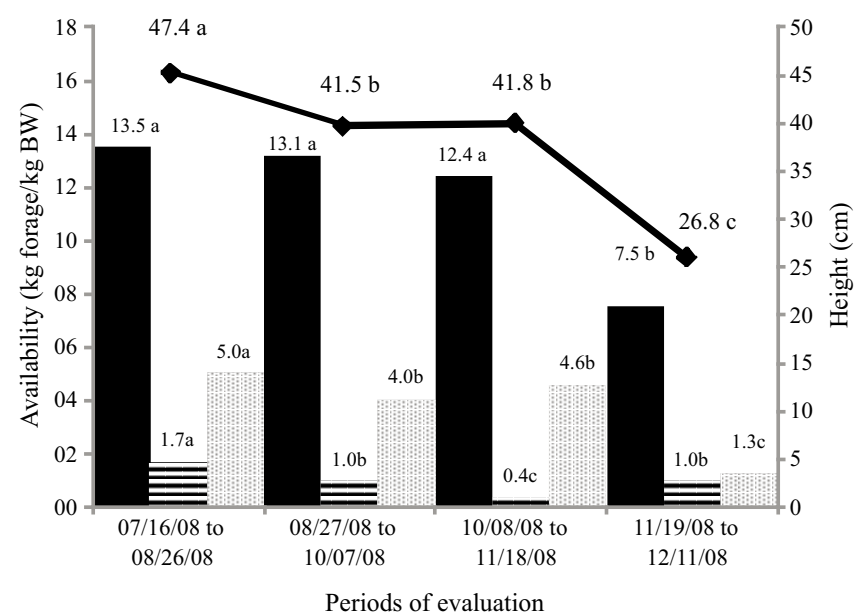

$$
\begin{aligned}
& \text { - Forage availability a Availability of green leaves } \\
& \text { 目Availability of senescing leaves } \longrightarrow \text { Sward height }
\end{aligned}
$$

Means followed by different lowercase letters in the variables are different by the Tukey test $(\mathrm{P}<0.05)$

Figure 2 - Quantitative characteristics of the forage sward of marandu grass during the dry period.
Paddocks were closed three months before the beginning of the experiment, in April 2008, for the forage mass not to limit animal performance during the dry period, and therefore, in a system managed under continuous grazing, it was expected that the forage availability levels would reduce as the periods passed. However, the little plant growth and adequate stocking rate for the period, 1.6 AU/ha, made it possible to maintain the mass in the first three periods (Figure 2).

The decrease in forage availability of the last period did not impair animal performance, and was due mainly to two factors; one of them, especially, was increase $(\mathrm{P}<0.05)$ of stocking rate to $1.8 \mathrm{AU} / \mathrm{ha}$ caused by increase in the weight of the experimental animals, and another was the incorporation of senescing material into the soil, which can also be elucidated when we observe the availability of dead leaves in this period in relation to the other experimental periods (Figure 2). This period coincides with the beginning of the rainy season, which promotes regrowth of pastures, reducing the senescing material and elevating the proportion of green leaves.

The availability of green and senescing leaves had different behaviors over the experiment. There was constant reduction $(\mathrm{P}<0.05)$ in the availability of senescing leaves from the first to the last period, probably because of the animal ingestion (Figure 2), since in this forage shortage period the availability is not enough for animals to only consume green leaves, stimulating the consumption of senescing leaves. Green leaf availability decreased $(\mathrm{P}<0.05)$ from the first to the third period, followed by an increase in the fourth period, probably due to the expressive plant growth in this last period, the month of November, characterized by increase in temperature and occurrence of rainfall (Figure 1), so it can be considered a period of transition from dry to rainy.

The proportions of green and senescing leaves followed the behavior of forage availability. The proportion of green stems increased $(\mathrm{P}<0.05)$ from the first to the second period, when the plant was at its reproductive stage, elongating stems, and then decreased from period 2 to 3 , which indicates senescence of this material (Figure 3). The proportions of senescing stem have a different behavior, increasing $(\mathrm{P}<0.05)$ from the first to the third period and stabilizing in the last one, when, as previously seen, there was increase in the green parts of the plant - stems and leaves -, as a response to the beginning of the rainy season and elevation in temperature (Figure 1).

Due mainly to climatic variations, which result in alterations in the sward structure and their association with ingestion and trampling by grazing animals, there 
were variations in the chemical composition of plants, modifying their nutritional value over the experimental periods (Figures 4, 5 and 6).

There was variation in the crude protein $(\mathrm{CP})$ of the forage over the period, remaining below $45 \mathrm{~g} / \mathrm{kg}$ DM in the samples of plant shoots (Figure 4). However, grazing animals selected the parts of the plant with highest nutritional value, i.e., green leaves, and during the dry period, senescing leaves too. Considering the results of the simulated grazing samples, the $\mathrm{CP}$ values were higher; they were highest $(\mathrm{P}<0.05)$ in the fourth period $(112 \mathrm{~g} / \mathrm{kg} \mathrm{DM})$, followed by the third (101 g/kg DM), first (75 g/ $\mathrm{kg} \mathrm{DM})$ and finally the second period, which had the lowest value $(56 \mathrm{~g} / \mathrm{kg} \mathrm{DM})$.

During the dry season of the year, tropical grasses showed a low nutritional value and lower protein content than the minimum of $70 \mathrm{~g} / \mathrm{kg} \mathrm{DM}$ for microorganisms to have conditions of utilizing the fibrous energy substrates of the forage ingested (Souza et al., 2010), but according to Lazzarini et al. (2009), the balance between nitrogen intake and synthesis of nitrogen compounds in the rumen can be achieved with supplementation of additional protein to the low-quality forage totaling $80 \mathrm{~g} / \mathrm{kg} \mathrm{CP}$ in the DM of the diet, which would be the minimum limit calculated by the these authors to enable maintenance of microbial growth.

Thus, animal performance on pasture during the dry period is usually not satisfactory, so it is necessary to supply concentrate supplements that correct the nutritional requirements of the pasture and result in better performance, reducing the production cycle and slaughter age of animals.

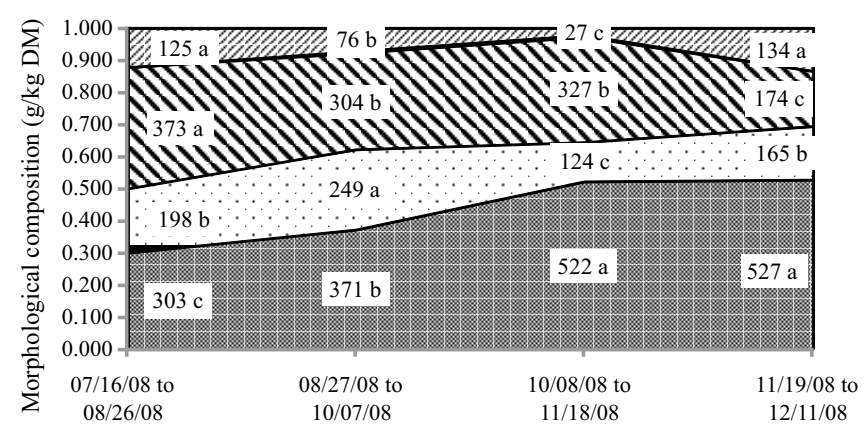

Periods of evaluation

$$
\begin{array}{ll}
\text { Senescing stems and sheaths } & \square \text { Green stems and sheaths } \\
\mathbf{Q} \text { Senescing leaves } & \square \text { Green leaves }
\end{array}
$$

Means followed by different lowercase letters in the variables are different by the Tukey test $(\mathrm{P}<0.05)$

Figure 3 - Morphological composition of the forage sward of marandu grass during the dry period.
In this context, considering only the $\mathrm{CP}$ contents of the grass, observing the samples of simulated grazing (Figure 4), they would be sufficient to maintain the weight of animals with no additional gain in the first period, implying loss of weight in period 2 and possibly resulting in moderate weight gain in periods 3 and 4 .

It is known, however, that weight gain in grazing animals is not a consequence of a single nutrient, but the set of factors. When it comes to the dry period of the year, we can say that the amount of forage available and the elevated proportion of the fiber of difficult degradation are the main factors.

The NDF contents observed were highest $(\mathrm{P}<0.05)$ in period $1(715 \mathrm{~g} / \mathrm{kg} \mathrm{DM})$, intermediary in periods 2 and 3 (685 and $677 \mathrm{~g} / \mathrm{kg} \mathrm{DM}$, respectively) and lowest in period $4(638 \mathrm{~g} / \mathrm{kg} \mathrm{DM})$, remaining close to $700 \mathrm{~g} / \mathrm{kg} \mathrm{DM}$ in the first three periods (Figure 5), which is in agreement with the many results in the literature on grass of the genus Brachiaria evaluated during the dry season of the year (Barbosa et al., 2007; Lima et al., 2012).

The acid detergent fiber (ADF) contents were higher in the second period of the experiment $(321 \mathrm{~g} / \mathrm{kg} \mathrm{DM})$ and lower $(\mathrm{P}<0.05)$ in the fourth period $(285 \mathrm{~g} / \mathrm{kg} \mathrm{DM})$. The lignin content of plants did not vary between experimental periods, remaining relatively low, since they were results of samples of simulated grazing, composed mainly of green and senescing leaves, following the harvesting pattern of grazing animals.

The reduction in the fiber contents, both NDF and ADF, observed in the fourth period are probably reflections of dilution, since these plants were growing, due to

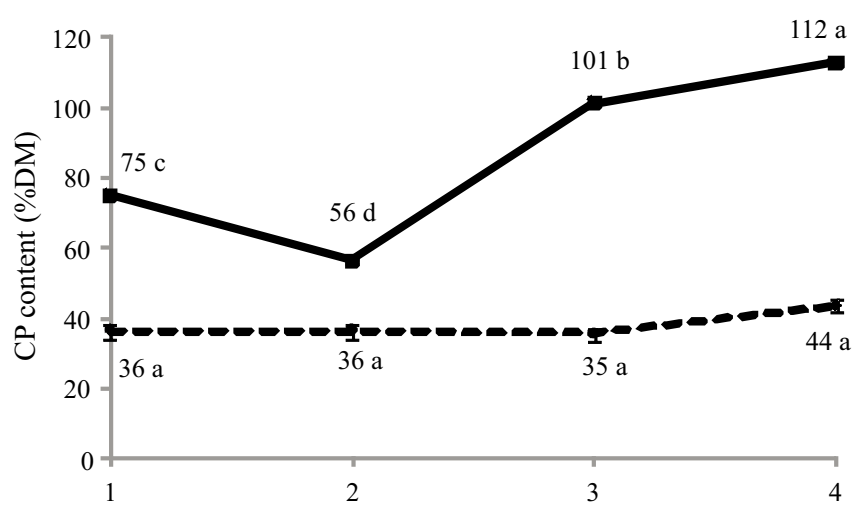

Periods of evaluation

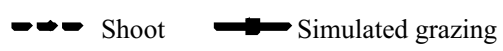

Means followed by different lowercase letters in the variables are different by the Tukey test $(\mathrm{P}<0.05)$.

Figure 4 - Crude protein (CP) contents in percentage of dry matter (DM) of shoots and simulated grazing of marandu grass during the dry period. 
the occurrence of rain and increase in the temperature (Figure 1), with consequent increase in the more digestible proportions, like green leaves, and thus greater uptake of more digestible nutrients to animals. The in vitro dry matter digestibility (Figure 6) in the last experimental period increased $(\mathrm{P}<0.05)$ as compared with periods 1,2 and 3.

The elevated fiber contents observed in the first periods, characterized by the NDF of tropical forages, can be associated with limitation in intake and, besides, we must consider that part of it will not be degraded in the rumen, because it is a component of the indigestible NDF fraction. This indigestible fraction is the result of the association of lignin with hemicellulose, which decreases the degradation of fiber in the rumen, because it hampers the access of microorganisms, negatively affecting their action. According to Lazzarini et al. (2009), protein supplementation can optimize the degradation of fiber in the rumen, which would consequently increase intake and result in improved performance.

In the first period the experimental animals which consumed protein+energy supplement presented greater $(\mathrm{P}<0.05)$ weight gain $(0.515 \mathrm{~kg} /$ day $)$ as compared with those fed protein supplement $(0.409 \mathrm{~kg} /$ day); this pattern remained so throughout the experimental periods (Figure 7).

The average daily gains in weight of animals in period 2, average of treatments (Figure 7), were the lowest $(\mathrm{P}<0.05)$ of all experiment, probably due to the lower uptake of protein provided by the forage (Figure 4). In relation to the type of supplementation, in period 2, animals supplemented with protein and energy presented superior gains $(0.238 \mathrm{~kg} /$ day $)$ to those supplemented only with protein $(0.070 \mathrm{~kg} /$ day $)(\mathrm{P}<0.05)$.

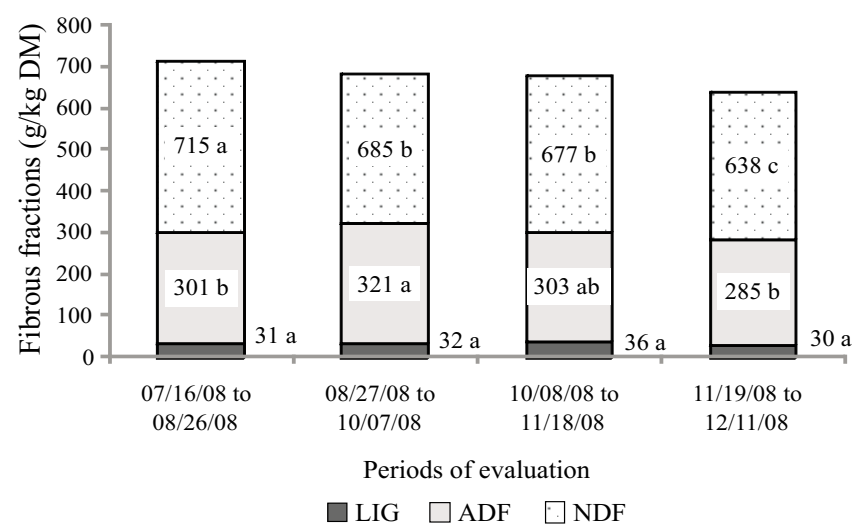

Means followed by different lowercase letters in the variables are different by the Tukey test $(\mathrm{P}<0.05)$.

Figure 5 - Contents of neutral detergent fiber (NDF g/ $\mathrm{kg} \mathrm{DM}$ ), acid detergent fiber (ADF $\mathrm{g} / \mathrm{kg} \mathrm{DM}$ ) and lignin (LIG g/kg DM) free of contamination by ash, of samples of simulated grazing of marandu grass during the dry period.
An important factor to be stressed is that the protein+energy supplement not only provides more TDN than the protein supplement, but the protein uptake is also superior, since the animals consume three times as much of this supplement, which may favor the growth of microorganisms that degrade the fiber in the rumen and consequently optimize the gain efficiency of these animals, since fiber is the main component of their diets (Figure 5).

The average daily gain in weight in period 3 (Figure 7) showed difference between the treatments; it was lowest in animals receiving protein supplement $(0.444 \mathrm{~kg} /$ day $)$ as compared with animals receiving protein+energy supplement $(0.577 \mathrm{~kg} /$ day $)$. The gains in weight of the animals in this period were higher $(\mathrm{P}<0.05)$ than in the

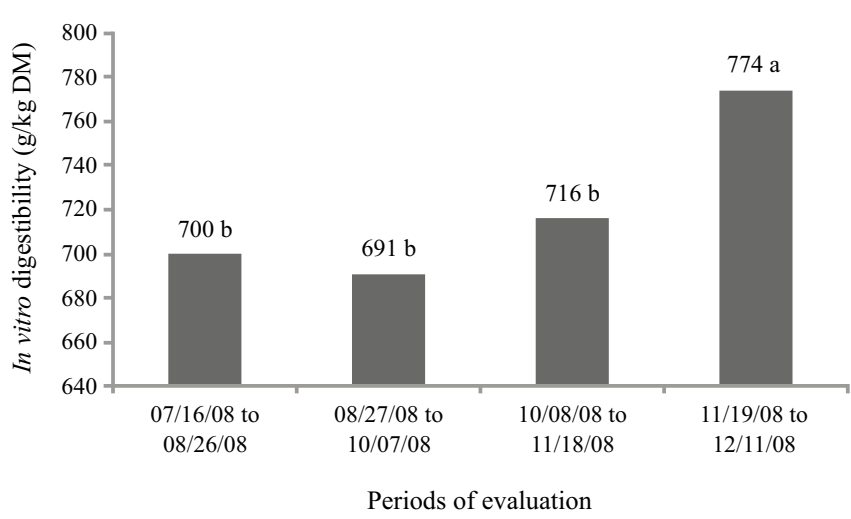

Means followed by different lowercase letters in the variables are different by the Tukey test $(\mathrm{P}<0.05)$.

Figure 6 - In vitro true dry matter digestibility content in percentage of dry matter of samples of simulated grazing of marandu grass in the dry period.

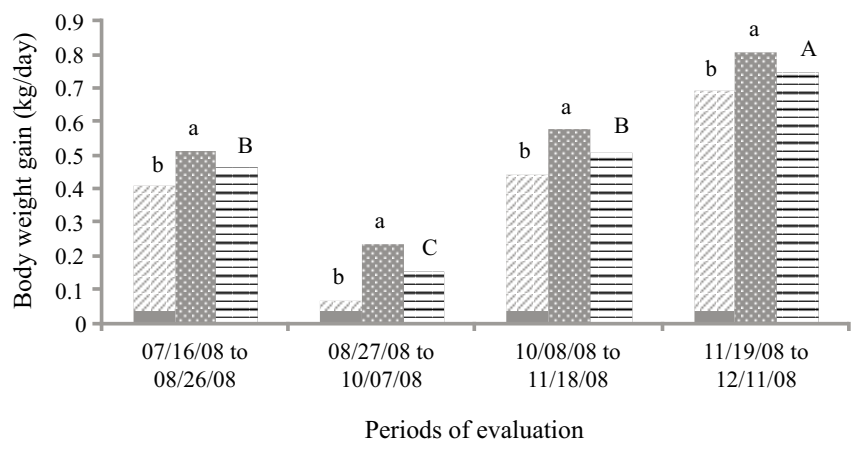

○Protein supplement $(1 \mathrm{~g} / \mathrm{kg}) \quad$ D Protein+energy supplement $(3 \mathrm{~g} / \mathrm{kg}) \quad \boxminus$ Average

Means followed by different lowercase letters in the variables and uppercase letters in the treatments in the periods are different by the Tukey test $(\mathrm{P}<0.05)$.

Figure 7 - Average daily gain, in kg per days, of Nellore young bulls fed protein supplement or protein+energy supplement on marandu grass pasture in the dry period. 
previous period and similar to the first period, probably because of the nutritional uptake provided by the forage, which in this period presented elevation in the $\mathrm{CP}$ content (Figure 4).

The fourth experimental period, comprising the months of November and December 2008, can be considered a transition from the dry to the rainy season, since we could observe increase in the proportion of green leaves, a little elevation in green stems at the expense of senescing leaves and maintenance of proportions of senescing stem (Figure 3). This structural change, elevated CP content (Figure 4) and increased digestibility (Figure 6) probably reflected in the greater weight gain of animals $(\mathrm{P}<0.05)$ as compared with the other periods, without modifying, however, the results of higher weight gain in animals fed protein+energy supplement $(0.808 \mathrm{~kg} /$ day $)$ as compared with those which received protein supplement $(0.691 \mathrm{~kg} / \mathrm{day})$ within this period.

Calculating the nutritional requirements of protein and energy for weight gain in experimental animals according to Valadares Filho et al. (2010), based on the average body weight of animals in each treatment $-233.75 \mathrm{~kg}$ in animals fed protein supplement (PS) and $239.95 \mathrm{~kg}$ in those consuming protein+energy supplement (PES) - we can observe that animals fed PES had a daily intake of $490 \mathrm{~g}$ TDN provided through the supplement, which is equivalent to the $17 \%$ of the energy requirement of this animal according to the weights observed, with an average $0.501 \mathrm{~kg} /$ day during the whole experiment (Table 2). We must also consider that this nutritional uptake might have contributed to the greater weight gain of animals fed PES as compared with those fed only PS, which depend on pasture to obtain energy, because the protein supplement does not have energy supply as a part of it, although it has grain meals in its composition, which implies a supply of a minimum amount of energy, but which is also disregarded.

Regarding protein supply, we can observe that animals fed protein supplement met $20 \%$ of their requirements, whereas those fed protein+energy supplement met
$28.6 \%$ of them. In quantitative terms, this difference was equivalent to $71 \mathrm{~g} \mathrm{CP}$ per animal per day via supplementation, allowing for greater weight gain in animals supplemented with protein and energy, since the basic conditions of diet and forage were the same. It is worth stressing the differential of protein requirement to elevate weight gain from $0.368 \mathrm{~kg} /$ day (protein supplement) to $0.510 \mathrm{~kg} /$ day (protein+energy supplement) (Table 2), which, according to Valadares Filho et al. (2010) is estimated at $72.1 \mathrm{~g} /$ animal.day. Since the additional uptake of protein from the protein+energy supplement in relation to the protein supplement is of $71 \mathrm{~g} / \mathrm{day}$, we can infer that the limiting factor of weight gain was the protein.

The initial body weight of Nellore animals did not present difference, with an average value of $204.8 \mathrm{~kg}$ (Table 2). The final body weight of animals was different $(\mathrm{P}<0.05)$ : animals fed protein+energy supplement showed heavier weight $(276.9 \mathrm{~kg})$, whereas animals receiving protein supplement had lower final body weight at the end of the dry period $(260.9 \mathrm{~kg})$, resulting in a difference of $16 \mathrm{~kg}$. These data corroborate Ladeira et al. (2007), who stated that the use of multiple supplements (protein and energy) can be an advantageous alternative during the dry season for all animal categories, bringing gains of 150 to $300 \mathrm{~g}$ /animal.day with the supply of 0.5 to $2 \mathrm{~g} / \mathrm{kg} \mathrm{BW}$.

Intentional supplementation of grazing animals provides limiting nutrients in the forage so as to optimize their performance and anticipate finishing, thus clearing areas of the property and delivering more homogeneous and young and lots, probably with a better carcass quality, to the slaughterhouse. Such goal was achieved both with utilization of protein supplement and protein+energy supplement; however, body weight gain at the end of the dry period was lower in animals fed the former and greater in those fed the more complete supplement, at a higher amount. These results demonstrate improvement in the rearing system that adopts this technology.

Regarding the observation of behavior of grazing animals, there was a significant difference $(\mathrm{P}<0.05)$ in the

Table 2 - Evaluations of performance of Nellore young bulls subjected to two supplementation levels, kept on a marandu grass over the dry season

\begin{tabular}{|c|c|c|c|c|c|}
\hline \multirow{2}{*}{ Variables } & \multicolumn{2}{|c|}{ Supplements } & \multirow{2}{*}{ Mean $^{2}$} & \multirow{2}{*}{$\mathrm{P}<\mathrm{F}^{3}$} & \multirow{2}{*}{$\mathrm{CV}$} \\
\hline & Protein $(1 \mathrm{~g} / \mathrm{kg} \mathrm{BW})$ & Protein+energy $(3 \mathrm{~g} / \mathrm{kg} \mathrm{BW})$ & & & \\
\hline Initial weight & 206.6 & 203.0 & 204.8 & 0.080 & 1.56 \\
\hline Final weight & $260.9 b$ & $276.9 \mathrm{a}$ & 268.9 & $* *$ & 2.34 \\
\hline Total ADG ${ }^{1}$ & $0.368 \mathrm{~b}$ & $0.501 \mathrm{a}$ & 0.435 & $* *$ & 10.56 \\
\hline
\end{tabular}

${ }^{1}$ Total weight gain.

${ }^{2}$ Mean average daily gain, in $\mathrm{kg} / \mathrm{day}$, of the whole experiment.

${ }^{3}$ Probability: $* * 0<0.01$

$\mathrm{CV}$ - coefficient of variation; BW - body weight.

Means followed by different lowercase letters in the row are different by the Tukey test $(\mathrm{P}<0.05)$. 
average time grazing in relation to treatments (Table 3). The animals which received protein supplement, as compared with those fed protein+energy supplement, spent more time grazing over the day, and the averages per period of the day were 2.23 and 2.06 hours, respectively. If we sum the grazing times over the 12 hours, we verify that animals grazed 8.61 hours on average. This result is close to that obtained by Zanine et al. (2006) with young bulls on Brachiaria brizantha pastures during daytime, an average of 7.48 hours.

At the evaluation of time spent grazing in the different periods of the day, there was difference $(\mathrm{P}<0.05)$ between the averages of periods (Table 3 ): in the late afternoon, longer grazing time was verified for animals in both treatments (2.65 hours). The period when animals spent more time for the grazing activity was late morning (1.82 hours), followed by early morning, at around $08 \mathrm{~h} 00$, negatively influencing their grazing in this period of the day, when they stopped grazing to ingest the supplement.

Observing the percentage of animals grazing throughout the day (Figure 8), we can see that grazing peaks occurred in the early morning, between $06 \mathrm{~h} 00$ and $07 \mathrm{~h} 00$, and late afternoon, starting at $17 \mathrm{~h} 00$, with greater intensity of animals grazing.

The moment supplement was offered to animals, 08h00, influenced their grazing behavior (Figure 8): all animals reduced grazing time to head to the trough; however, the percentage of animals fed protein+energy supplement remained reduced for a longer period after supplementation, probably because a higher amount of supplement was provided.

Therefore, we can infer that the grazing behavior of an animal is modified by the supply of supplements; it can be changed as a function of the time of supply, because animals apparently stop grazing to consume the supplement, so the practice of supplementation would have lower influence if supplements were provided at times when grazing intensity is lower.

Table 3 - Time spent grazing by Nellore young bulls in the periods of daylight, during the dry season (October 2008) on a marandu grass pasture according to the type of supplementation

\begin{tabular}{lccc}
\hline \multirow{2}{*}{ Time spent grazing } & \multicolumn{2}{c}{ Supplements } & \multirow{2}{*}{ Mean } \\
\cline { 2 - 3 } & Protein & Protein+energy & \\
\hline Early morning (6h00 to 8h50) & 2.1 & 1.9 & $1.98 \mathrm{BC}$ \\
Late morning (9h00 to 11h50) & 1.9 & 1.7 & $1.82 \mathrm{C}$ \\
Early afternoon (12h00 to 14h50) & 2.2 & 2.1 & $2.17 \mathrm{~B}$ \\
Late afternoon (15h00 to 17h50) & 2.7 & 2.6 & $2.65 \mathrm{~A}$ \\
Mean & $2.23 \mathrm{a}$ & $2.07 \mathrm{~b}$ & \\
\hline
\end{tabular}

Means followed by different lowercase letters in the row and uppercase letters in the column are different by the Tukey test at $5 \%$ probability.

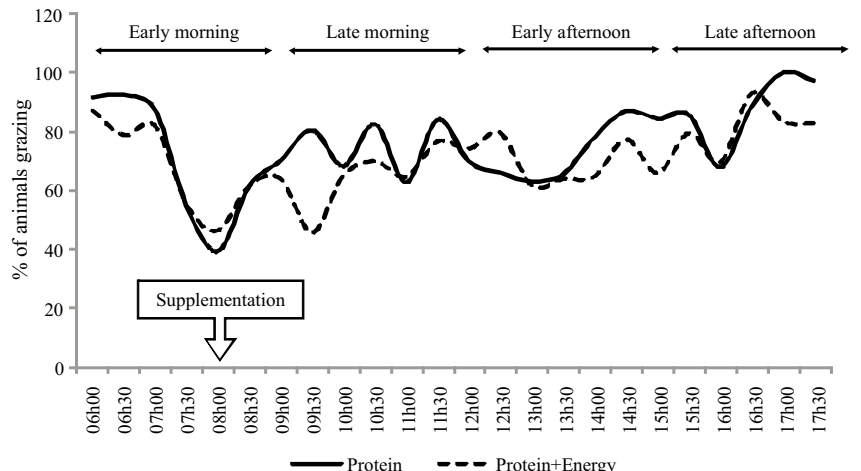

Figure 8 - Percentage of Nellore young bulls grazing in each period of daylight, during the dry season (October 2008), on a marandu grass pasture, receiving protein or protein+energy supplement.

\section{Conclusions}

Supplementing Nellore young bulls in the dry period of the year with protein+energy supplement promotes greater weight gain as compared with protein supplement, which allows for higher final weight at the end of this period under the same conditions of forage availability and stocking rate. The type of supplement and level of supplementation interfere with the ingestive behavior of young bulls: animals receiving protein+energy supplement graze longer as compared with those fed protein supplement.

\section{Acknowledgements}

To Bellman Nutrição Animal for the partnership and for supplying the supplements utilized in this project.

\section{References}

ASSOCIATION OF OFFICIAL ANALYTICAL CHEMISTRY AOAC. Official methods of analysis. 15.ed. Arlington: AOAC International, 1990.

BAIÃO, A.A.F.; ANDRADE, I.F.; BAIÃO, E.A.M. et al. Desempenho de novilhos mestiços Nelore suplementados em pastagem com diferentes níveis de concentrado no período seco do ano. Ciência e Agrotecnologia, v.29, n.6, p.1258-1264, 2005.

BARBOSA, F.A.; GRAÇA, D.S.; MAFFEI, W.E. et al. Desempenho e consumo de matéria seca de bovinos sob suplementação protéicoenergética, durante a época de transição água-seca. Arquivo Brasileiro de Medicina Veterinária e Zootecnia, v.59, n.1, p.160-167, 2007.

EUCLIDES, V.P.B.; EUCLIDES FILHO, K. Avaliação de forrageiras sob pastejo. In: SIMPÓSIO SOBRE AVALIAÇÃO DE PASTAGENS COM ANIMAIS, 1997, Maringá. Anais... Maringá: UEM, 1997. p.85-111.

HADDAD, C.M.; MENDES, C.Q. Manejo da estação de monta, das vacas e das crias. In: PIRES, A.V. (Ed.) Bovinocultura de corte. Piracicaba, FEALQ, 2010. v.1, p.760. 
LADEIRA, M.M.; RIBEIRO, J.S.; MACHADO NETO, O.R., et al. Alternativas para o manejo nutricional de bovinos de corte a pasto, no período da seca. In: SIMPÓSIO DE PECUÁRIA DE CORTE, 5., 2007, Lavras. Anais... Lavras, 2007. p.87-117.

LAZZARINI, I.; DETMANN, E.; SAMPAIO, C.B. et al. Dinâmicas de trânsito e degradação da fibra em detergente neutro em bovinos alimentados com forragem tropical de baixa qualidade e compostos nitrogenados. Arquivo Brasileiro de Medicina Veterinária e Zootecnia, v.61, n.3, p.635-647, 2009.

LIMA, H.L.; GOES, R.H.T.B.; CERILO, S.L.N. et al. Nutritional value of Marandu grass, under grazing by three sampling methods. Acta Scientiarum, v.34, n.4, p.379-384, 2012.

PAULINO, M.F.; ZERVOUDAKIS, J.T.; MORAES, E.H.B.K. et al. In: SIMPÓSIO DE PRODUÇÃO DE GADO DE CORTE, 3., 2002, Viçosa, MG. Anais... Viçosa, MG: UFV, 2002. p.153-196.

REIS, R.A.; BERTIPAGLIA, L.M.A.; FREITAS, D. et al. Suplementação protéico-energética e mineral em sistemas de produção de gado de corte nas águas e nas secas. In: SIMPÓSIO SOBRE BOVINOCULTURA DE CORTE: REQUISITOS DE QUALIDADE NA BOVINOCULTURA DE CORTE, 5., 2004, Piracicaba. Anais... Piracicaba: FEALQ, 2004. p.171-226.

ROBERTSON, J.B.; VAN SOEST, P.J. The detergent system of analysis and its application to human foods. In: JAMES, W.P.T.;
THEANDER, O. (Eds.) The analysis of dietary fiber in food. New York: Marcel Dekker, 1981. p.123-158.

SNIFFEN, C.J.; O'CONNOR, J.D.; VAN SOEST, P.J. et al. A net carbohydrate and protein system for evaluating cattle diets: II. Carbohydrate and protein availability. Journal of Animal Science, v.70, p.3562-3577, 1992.

SOLLENBERGER, L.E.; CHERNEY, D.J.R. Evaluating forage production and quality. The science of grassland agriculture. Iowa: Iowa State University Press, 1995. p.97-110.

SOUZA, M.A.; DETMANN, E.; PAULINO, M.F. et al. Intake, digestibility and rumen dynamics of neutral detergent fibre in cattle fed lowquality tropical forage and supplemented with nitrogen and/or starch. Tropical Animal Health and Production, v.42, p.1299-1310, 2010.

VALADARES FILHO, S.C.; MACHADO, P.A.S.; CHIZZOTTI, M.L. et al. Tabelas brasileiras de composição de alimentos para bovinos. Viçosa, MG: UFV, 2010. 502p.

VAN SOEST, P.J. Nutritional ecology of the ruminant. 2.ed. Ithaca: Cornell University Press, 1994. 476p.

VAN SOEST, P.J.; ROBERTSON, J.B. Analysis of forages and fibrous foods. Ithaca: Cornell University Press, 1985. 202p.

ZANINE, A.M.; SANTOS, E.M.; PARENTE, H.N. et al. Comportamento ingestivo de bezerros em pastos de Brachiaria brizantha e Brachiaria decumbens. Ciência Rural, v.36, n.5, p.1540-1545, 2006. 